\title{
Identification of mutation-specific tumor infiltrating lymphocytes from metastatic ovarian cancer
}

\author{
Drew C Deniger ${ }^{1 *}$, Mini Bharathan ${ }^{1}$, Pasetto Anna², Eric Tran², Jared J Gartner ${ }^{2}$, Todd D Prickett ${ }^{3}$, Paul F Robbins², \\ Steven A Rosenberg ${ }^{2}$
}

From 30th Annual Meeting and Associated Programs of the Society for Immunotherapy of Cancer (SITC 2015)

National Harbor, MD, USA. 4-8 November 2015

\section{Introduction}

Novel interventions are needed for the treatment of women with metastatic ovarian cancer that causes 14,000 deaths each year in the USA. Retrospective analysis of tumor infiltrating lymphocytes (TIL) infused into patients who achieved complete, durable regressions of metastatic melanoma revealed that the responses were likely mediated through recognition of somatic non-synonymous mutations. Furthermore, prospective administration of mutation-specific TIL resulted in an ongoing partial response in a patient with cholangiocarcinoma.

\section{Methods}

We now studied whether TIL obtained from metastatic ovarian cancer recognized tumor mutations. Exome and transcriptome sequencing was performed from resected metastatic ovarian cancer deposits in parallel with growth of TIL fragment cultures in IL-2. Long peptides and tandem minigenes (TMGs) encompassing all mutations were synthesized, introduced into autologous antigen presenting cells, co-cultured with individual TIL fragments and T cell reactivity was determined by interferon- $\gamma$ ELISPOT and surface expression of 41BB.

\section{Results}

In patient 4046 (280 mutations), 8 of 24 fragments were reactive to TMG15 $\left(86.9 \% \pm 1.5 \% 41 \mathrm{BB}^{+} \mathrm{T}\right.$ cells; mean \pm SEM). Co-culture with individual long peptides corresponding to the mutations in TMG15 revealed that the $\mathrm{T}$ cells recognized the USP9X ${ }^{\mathrm{Y} 373 \mathrm{C}}$ mutation, a putative tumor suppressor gene on the $\mathrm{X}$ chromosome. Two of 14 fragments from patient 4067 (122 mutations) were

${ }^{1} \mathrm{NIH} / \mathrm{NCl}$, Bethesda, MD, USA

Full list of author information is available at the end of the article responsive to autologous tumor and a cumulative $41 \mathrm{BB}^{+}$ expression was observed at $51 \%$ and $8 \%$ in $\mathrm{CD}^{+}$and $\mathrm{CD} 8^{+} \mathrm{T}$ cells, respectively, following co-culture with TMG2, TMG5, TMG6 and TMG7. Using UV-exchangeable peptide tetramers, the following candidate minimal epitopes from this patient were identified: $\mathrm{ZWILCH}^{\mathrm{S} 296 \mathrm{~F}}$ from TMG2, SPINT2 ${ }^{\mathrm{H} 35 \mathrm{~L}}$ and TNPO1 ${ }^{\mathrm{M} 697 \mathrm{~K}}$ from TMG5, HIST1H1C ${ }^{\mathrm{K} 181 \mathrm{R}}$ from TMG6, and SUN2 $2^{\mathrm{P} 117 \mathrm{~S}}$ and HIST1H1C ${ }^{\mathrm{D} 72 \mathrm{G}}$ from TMG7. Patient 4097 (332 mutations) had 3 of 24 fragments with recognition of autologous tumor and $\mathrm{CD}^{+} \mathrm{T}$ cell reactivity $(53 \%, 74 \%$ and $81 \% 41 \mathrm{BB}^{+}$) to mutated HIST1H1B ${ }^{\mathrm{A} 71 \mathrm{D}}$ peptide. These fragments had $11 \%$ cumulative $\mathrm{CD}^{+} 41 \mathrm{BB}^{+}$ $\mathrm{T}$ cells when co-cultured with mutated $\mathrm{DEF} 6^{\mathrm{L} 319 \mathrm{Q}}$, $\mathrm{GAK}^{\mathrm{V} 534 \mathrm{M}}$ and FLOT1 ${ }^{4-11 \text { del }}$ peptides. A fourth fragment had $6 \% \mathrm{CD}^{+} 41 \mathrm{BB}^{+} \mathrm{T}$ cells in response to mutated INPP5K $\mathrm{K}^{\mathrm{L} 176 \mathrm{~V}}$ peptide.

\section{Conclusions}

In summary, mutation-specific $\mathrm{T}$ cell responses were found in 3 of 4 patients with metastatic ovarian cancer, which opens the opportunity to use these cells for adoptive $\mathrm{T}$ cell treatment of advanced ovarian cancer.

\section{Authors' details}

${ }^{1} \mathrm{NIH} / \mathrm{NCl}$, Bethesda, MD, USA. ${ }^{2}$ Surgery Branch/National Cancer Institute / National Institutes of Health, Bethesda, MD, USA. ${ }^{3} \mathrm{NCI} / \mathrm{NIH}$, Bethesda, MD, USA.

Published: 4 November 2015

doi:10.1186/2051-1426-3-S2-P10

Cite this article as: Deniger et al:. Identification of mutation-specific tumor infiltrating lymphocytes from metastatic ovarian cancer. Journal for ImmunoTherapy of Cancer 2015 3(Suppl 2):P10. 